\title{
Overview of Known Alkaliphilic Bacteria from Bauxite Residue
}

\author{
Bruna Del Busso Zampieri ${ }^{1}$, Elis Watanabe Nogueira ${ }^{2}$, Osvail André Quaglio ${ }^{3}$ and Gunther Brucha ${ }^{3 *}$ \\ ${ }^{1}$ Department of Biochemistry and Microbiology, School of Biology, São Paulo State University, Brazil \\ ${ }^{2}$ Biological Processes Laboratory (LPB), School of Engineering (EESC), University of São Paulo, Brazil \\ ${ }^{3}$ School of Technological Sciences, Federal University of Alfenas, Brazil \\ *Corresponding author: Gunther Brucha, School of Technological Sciences, Federal University of Alfenas, Brazil
}

\begin{abstract}
Alkaliphilic bacteria usually grow well at $\mathrm{pH}$ 9, and the most extremophilic strains can grow up to values as high as pH 12-13. This group of bacteria has the ability to metabolically reduce alkalinity and are tolerant of high concentrations of ions and metals. Interest in extreme alkaliphiles has been shown as they are sources of useful, stable enzymes, and the cells themselves can be used for biotechnological and other applications at high $\mathrm{pH}$ values. Many industrial processes produce highly alkaline waste that is contaminated with toxic trace metals/metalloid. Thus, using alkaliphilic microorganisms is considered an attractive alternative method for treating industrial alkaline residues. Bauxite refining is one of the activities that most produces highly alkaline waste. Alumina extraction from bauxite using concentrated sodium hydroxide in the Bayer process generates a slurry and an extremely alkaline ( $\mathrm{pH}$ of 9 to 13) by-product known as bauxite residue or red mud. For each ton of alumina extracted from bauxite, approximately 1.5-2.0 tons of bauxite residue is generated. Disposal of such a by-product is a serious problem at alumina plants because of environmental risks and financial costs. Thus, it is very important to know bacteria that can survive in such an extreme environment since these bacteria could be used as a method for treating alkaline residues. Firmicutes have been described as one of the most representative bacterial phyla in bauxite residue, and the Bacillus genus as one of the most frequent. Different species of Bacillus have already been isolated from red mud and have shown great potential for the bioremediation process. For this reason, the aim of this article is to carry out a literature review on alkaliphilic bacteria isolated from red mud.
\end{abstract}

\section{Introduction}

Bauxite residue (BR) is generated during bauxite refining for aluminum production through the Bayer process. The Bayer process used to extract alumina consists of adding sodium hydroxide and lime to bauxite and subsequent thermal treatment of this material [1], forming an alkaline waste known as red mud. The BR has a high concentration of soluble ions, $\mathrm{pH}$ between 9 and 13 and a low concentration of organic carbon and nutrients [2]. According to the World Aluminium Organization (2018), the bauxite production in 2017 was around $327 \mathrm{Mt}$, it generated $202 \mathrm{Mt}$ of bauxite residue and continued to increase by approximately 150 million tonnes per year [3]. Due to environmental issues and the high cost associated with managing and disposing of it, there is a growing concern about the proper disposal of this waste. Alternative uses of BR have been studied in the ceramics industry [4], stabilizer soil [5] and metal recovery, among others [2]. However, there are some limitations, such as excess in moisture, hazardous rating of bauxite residue, viable logistics in the transport of waste and the low aggregate value in BR. The most common storage method of red mud is in tailing dams, which requires efforts to manage the waste, and the risk of dam failures has become a global concern. Disasters which happened in Hungary in 2010 and in Brazil in 2015 have been considered two of the largest mining environmental catastrophes and have drawn attention due to the high risk of contamination to the environment and social problems [6-9].

A viable alternative that may help to solve this waste is by using autochthonous alkaliphilic microorganisms in BR. They are key pieces for alkaline effluent bioremediation such as red mud, which requires biological neutralization due to the high risks associated with the neutralization by chemical agents. On the other hand, the application of these extremophilic microorganisms in the areas of biotechnology has also been studied extensively due to the enzymes and bioactive compounds produced by alkaliphilic bacteria [10]. Alkaliphilic bacteria are able to develop in extreme environments, they are generally tolerant of the presence of high levels of sodium 
and metals, and low levels of available organic carbon and nutrients. The main aim of this study is to provide an overview of alkaliphilic bacteria found in red mud, focusing on the isolated species of those bacteria until now, their capability of acid compound production according to the carbon source used and their potential use as a $\mathrm{pH}$ reducing agent in red mud. These issues may shed light on new opportunities to reduce the environmental impact promoted by this mining waste.

\section{Bauxite Residue Characterization}

Bauxite residue, also known as red mud, is an insoluble byproduct generated from the extraction of alumina from bauxite during the Bayer process (Figure 1), a crucial step in manufacturing aluminum. Solid waste residue is generated from the digestion of bauxite ores with caustic soda for alumina $\left(\mathrm{Al}_{2} \mathrm{O}_{3}\right)$ production [11]. Thus, BR is highly alkaline, about 11-13 [12], and difficult to deal with, representing a significant environmental hazard [13]. Extensive research and development studies for the storage, disposal and use of red mud/bauxite residue are being carried out all over the world [14]. Typically, red mud has been dumped in minedout pits or red mud ponds. Up to 2 tonnes of liquor with significant alkalinity of 5-20 $\mathrm{g} \mathrm{l}^{-1}$ caustic soda (as $\mathrm{Na}_{2} \mathrm{CO}_{3}$ ) accompany every tonne of dry mud [15]. Table 1 shows the compositional matrix of the red mud. The dissolution of desilication products such as sodalite and cancrinite, with associated amorphous secondary phase, generates more alkalinity and releases sodium in the long term (Equation 1 and 2) [12].

$\mathrm{Na}_{6}\left(\mathrm{Al}_{6} \mathrm{Si}_{6} \mathrm{O}_{24}\right) \cdot 2 \mathrm{NaOH}+24 \mathrm{H}_{2} \mathrm{O} \leftrightarrow 8 \mathrm{Na}++8 \mathrm{OH}-+6 \mathrm{Al}(\mathrm{OH})_{3}+6 \mathrm{H}_{4} \mathrm{SiO}_{4}(1)$

$\mathrm{Na}_{6}\left(\mathrm{Al}_{6} \mathrm{Si}_{6} \mathrm{O}_{24}\right) \cdot 2 \mathrm{CaCO}_{3}+26 \mathrm{H}_{2} \mathrm{O} \leftrightarrow 6 \mathrm{Na}^{+}+2 \mathrm{Ca}^{+2}+8 \mathrm{OH}^{+}+2 \mathrm{HCO}_{3}^{-}$ $+6 \mathrm{Al}(\mathrm{OH})_{3}+6 \mathrm{H}_{4} \mathrm{SiO}_{4}(2)$

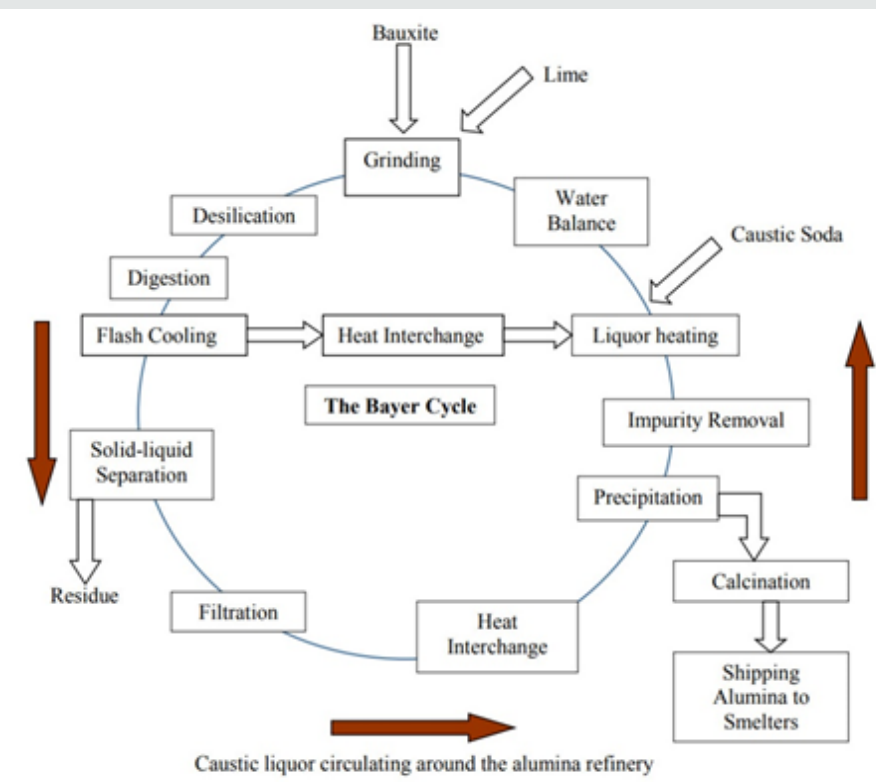

Figure 1: Bayer process for the production of alumina from bauxite. [49].

Table 1: Compositional matrix of the red mud (X-ray fluorescence data). Yoon et al. 2019

\begin{tabular}{|c|c|c|}
\hline \multicolumn{2}{|c|}{ Red Mud } \\
\hline Element & Compound Formula & Wt. Percent (\%) \\
\hline $\mathrm{Fe}$ & $\mathrm{Fe}_{2} \mathrm{O}_{3}$ & 22.8 \\
\hline $\mathrm{Al}$ & $\mathrm{Al}_{2} \mathrm{O}_{3}$ & 17.1 \\
\hline $\mathrm{Si}$ & $\mathrm{SiO}_{2}$ & 11.5 \\
\hline $\mathrm{Na}$ & $\mathrm{Na}_{2} \mathrm{O}$ & 7.92 \\
\hline $\mathrm{Ti}$ & $\mathrm{TiO}_{2}$ & 2.52 \\
\hline $\mathrm{Ca}$ & $\mathrm{CaO}_{2}$ & 0.518 \\
\hline $\mathrm{Zr}$ & $\mathrm{ZrO}_{2}$ & 0.247 \\
\hline $\mathrm{S}$ & $\mathrm{SO}_{3}$ & \\
\hline
\end{tabular}




\begin{tabular}{|c|c|c|}
\hline $\mathrm{Cr}$ & $\mathrm{Cr}_{2} \mathrm{O}_{3}$ & 0.135 \\
\hline $\mathrm{P}$ & $\mathrm{P}_{2} \mathrm{O}_{5}$ & 0.126 \\
\hline $\mathrm{Mn}$ & $\mathrm{MnO}$ & 0.053 \\
\hline $\mathrm{K}$ & $\mathrm{K}_{2} \mathrm{O}$ & 0.045 \\
\hline $\mathrm{Pb}$ & $\mathrm{PbO}$ & 0.034 \\
\hline $\mathrm{Cl}$ & $\mathrm{Cl}$ & 0.028 \\
\hline $\mathrm{Y}$ & $\mathrm{Y}_{2} \mathrm{O}_{3}$ & 0.023 \\
\hline Total & & 100 \\
\hline
\end{tabular}

\section{Challenges in the treatment of bauxite residue}

An enormous amount of BR is generated worldwide every year, leading to a dangerous environmental and safety problem. Alumina refineries have a huge challenge in the storage of red mud as storage pond dams sometimes collapse and/or fail due to heavy rains that cause flooding and breaching [16]. One example of this issue is that in October 2010 in Hungary, one corner of a red mud reservoir dam from the Ajka Timföldgyár alumina plant collapsed. The $50 \mathrm{~m}$ wide break released $700,000 \mathrm{~m}^{3}$ of caustic red mud slurry into three villages and the surrounding countryside streams and rivers, which drain into the Danube River. This poses as a serious environmental problem, in addition to problems that people living around these areas may experience $[17,18]$. On the other hand, the global demand for aluminum metal has increased, and so has the demand for alumina and, as a result, bauxite residue production. Red mud poses disturbing risks to the environment due to its large volume, high alkalinity, and storage complications [19]. The high alkalinity $(\mathrm{pH} \geq 13$ ) and high caustic $(\mathrm{NaOH})$ contents in BR pose a risk to the environment as they can interfere in soil fertility and contaminate groundwater (making it unable to support plant life). Besides that, this kind of residue leads to human health risks such as skin problems and eye irritation [20].

In order to decrease this risk, the alkalinity of bauxite residue needs to be lowered to around $8.0 \mathrm{pH}$. Thus, the environmental risk of this storage can be reduced due to the need of management in this area, besides facilitating the potential reuse of this material in different applications. However, the buffering action of alkaline solids (hydroxides, carbonates, and aluminates) present in this residue causes amorphous secondary phases that generate further alkalinity and release sodium in the long term. Therefore, the $\mathrm{pH}$ neutralization process is complex, requiring multiple time-sensitive steps [18]. One of the strategies to try to find a solution to this problem regarding bauxite residue treatment is microbiological treatment. The use of alkaliphilic microorganisms is considered an attractive alternative method for treating industrial alkaline residues, owing to their ability to metabolically reduce alkalinity and their tolerance of high concentrations of ions and metals and low availability of organic carbon and nutrients [21].

\section{Microorganism from bauxite residue}

Interest in extreme alkaliphiles is increasing because they have stable enzymes and the cells themselves can be used for biotechnological and other applications at high $\mathrm{pH}$ values. This group has many adaptations to survive at high $\mathrm{pH}$ values. For example, they can maintain a cytoplasmic $\mathrm{pH}$ significantly lower than the highly alkaline external through continuous availability of cation efflux [22], and they can also produce acids in order to neutralize the high $\mathrm{pH}$ [21]. Bioremediation uses these metabolic properties of microorganisms to solve the problems of residue treatment. However, it has been relatively underexplored [23]. Ghorbani et al. [24], Hamdy and Williams et al. [25], Krishna et al. [23], Vachon et al. 1994, among others, studied the treatment of bauxite residue through microorganism activity. Thus, some efforts have been made in the research area to isolate alkaliphilic microorganisms from red mud. Some of these isolated strains can be found in Table 2. Species from genus Bacillus are the most frequently isolated in these areas. Proteobacteria and Firmicutes have been described as two of the most representative bacterial phyla in BR [10]. Agnew et al. [26] isolated three strains JaA, JaD and JaH from the BR and characterized them following enrichment at $\mathrm{pH}$ 10. The JaH strain was a new Bacillus species and was called Bacillus vedderi showing the potential importance of this bacteria in biotechnological processes. The same species studied for Agnew et al. [26] were isolated for Nogueira et al. [21], showing the dominance of this group in the bauxite residue. The three strains isolated from Bauxite residue in the Southern region of Minas Gerais, Brazil [21] called BRA1, BRA3 and BRA5 were identified as B. cohnii, B. pseudofirmus and B. clarkii, respectively. The growth range was between $\mathrm{pH} 7$ and 10 and was tolerant of concentrations of 0 to $10 \% \mathrm{NaCl}$. They were capable of metabolising the following sugars: glucose, fructose, sucrose and mannitol and the higher amount of acids produced from the carbon sources were acetic, isobutyric, isovaleric, among others. The strains BRA1, BRA3 and BRA5 showed the ability to reduce the $\mathrm{pH}$ of a strongly alkaline medium from 10.5 to approximately 9.3, 9.5 and 9, respectively Table 3. Bacillus sp. is a genus often isolated in alkaline environments. It has several adaptations to survive in extreme high $\mathrm{pH}$ values. The cell walls in alkaliphilic Bacillus spp., in addition to peptidoglycan, also have some acidic polymers, such as phosphoric acid, galacturonic acid, aspartic acid, gluconic acid and glutamic acid [27]. These acids promote negative charges to the cell wall and give the cell surface the ability to adsorb sodium and hydronium ions and repulse hydroxide ions and, as a consequence, may help cells to grow in alkaline environments [28]. Plasma membranes 
may also maintain $\mathrm{pH}$ homeostasis by using the $\mathrm{Na}+\mathrm{H}+$ antiporter system $\left(\Delta \psi\right.$ dependent and $\Delta \mathrm{pH}$ dependent), the $\mathrm{K}^{+} / \mathrm{H}^{+}$antiporter, and ATPase-driven $\mathrm{H}^{+}$expulsion [28]. Other studies [23] isolated other genera, such as Kokuria sp, Psedomonas sp. and Planococcus $s p$. In addition, they presented the first study on bacterial diversity in bauxite residue. Some physiological characteristics of the isolated strains can be seen in Table 4.

Table 2: List of alkaliphilic bacteria and fungi isolated from red mud.

\begin{tabular}{|c|c|c|c|}
\hline Strain & Source & Year of isolation & Reference \\
\hline $\begin{array}{c}\text { Strains JaA, JaD and JaH, the last one named as Bacillus } \\
\text { vedderi JaH }\end{array}$ & Bauxite-processing red mud tailing pond & 1995 & {$[26]$} \\
\hline $\begin{array}{l}150 \text { cultures isolated, most identified to the genera: Lacto- } \\
\text { bacillus, Leuconostoc and Bacillus }\end{array}$ & BR lake deposit at Mobile, AL, USA. & - & {$[25]$} \\
\hline Kocuria sp & $\begin{array}{l}\text { Red mud pond impoundment of National Alu- } \\
\text { minium Company Limited (NALCO), Damanjodi, } \\
\text { Orissa (India) }\end{array}$ & 2008 & $\begin{array}{l}\text { Krishna et al. } \\
\quad(2008)\end{array}$ \\
\hline $\begin{array}{c}\text { Agromyces indicus } \\
\text { Bacillus litoralis } \\
\text { Bacollus anthracis } \\
\text { Chungangia koreensis } \\
\text { Kokuria flava } \\
\text { Kokuria polaris } \\
\text { Microbacterium hominis } \\
\text { Planococcus plakortidis } \\
\text { Pseudomonas alcaliphila } \\
\text { Salinococcus roseus }\end{array}$ & $\begin{array}{l}\text { Red mud pond impoundment of National Alu- } \\
\text { minium Company Limited (NALCO), Damanjodi, } \\
\text { Orissa (India) }\end{array}$ & 2014 & [23] \\
\hline Fungis Ascomycota Basidiomycota & Tailing stored from Germany and Australia & - & [10] \\
\hline $\begin{array}{l}\text { Bacillus cohnii } \\
\text { Bacillus pseudofirmus } \\
\text { Bacillus clarkia }\end{array}$ & Bauxite residue - Minas Gerais (Brazil) & 2013 & [21] \\
\hline Penicillium oxalicum EEEL01 & $\begin{array}{l}\text { Bauxite residue deposit area, Guangxi Province, } \\
\text { China }\end{array}$ & - & [29] \\
\hline Bacillus sp EEEL02 & $\begin{array}{l}\text { Bauxite residue deposit area, Guangxi Province, } \\
\text { China }\end{array}$ & - & {$[52]$} \\
\hline
\end{tabular}

Table 3: Analysis of growth and $\mathrm{pH}$ in cultures of the isolates, with different carbohydrates as a carbon source [21].

\begin{tabular}{|c|c|c|c|c|c|c|c|c|c|}
\hline \multirow[b]{2}{*}{ Carbohydrate } & \multicolumn{3}{|c|}{ B. cohnii } & \multicolumn{3}{|c|}{ B. pseudofirmus } & \multicolumn{3}{|c|}{ B. clarkia } \\
\hline & Max. growth ${ }^{1}$ & $\begin{array}{l}\text { Max. pH de- } \\
\text { crease }^{2}\end{array}$ & Min. $\mathrm{pH}^{3}$ & $\begin{array}{l}\text { Max. } \\
\text { growth }\end{array}$ & $\begin{array}{c}\text { Max. } \mathrm{pH} \\
\text { decrease }\end{array}$ & Min. $\mathrm{Ph}$ & $\begin{array}{l}\text { Max. } \\
\text { growth }\end{array}$ & $\begin{array}{l}\text { Max. pH } \\
\text { decrease }\end{array}$ & Min. $\mathrm{pH}$ \\
\hline Glucose & 1.54 & 1.26 & 9.2 & 1.65 & 0.96 & 9.51 & 1.2 & 1.43 & 9.04 \\
\hline Fructose & 0.525 & 0.5 & 10.1 & 0.53 & 0.45 & 10.14 & 0.4 & 0.4 & 10.18 \\
\hline Sucrose & 0.461 & 0.52 & 10.05 & 0.53 & 0.44 & 10.13 & 0.4 & 0.44 & 10.14 \\
\hline Mannitol & 0.714 & 0.85 & 9.7 & 0.75 & 0.45 & 10.06 & 0.56 & 0.53 & 9.97 \\
\hline Lactate & 0.09 & 0.32 & 10.26 & 0.09 & 0.46 & 10.12 & 0.15 & 0.39 & 10.18 \\
\hline Xylose & 0.09 & 0.35 & 10.2 & 0.09 & 0.43 & 10.11 & 0.22 & 0.41 & 10.13 \\
\hline Yeast extract & 0.12 & 0.24 & 10.34 & 0.12 & 0.37 & 10.22 & 0.25 & 0.39 & 10.2 \\
\hline
\end{tabular}


Table 4: Effect of bacteria on the growth and physico-chemical structure of bauxite residue after 6 months of inoculation [23].

\begin{tabular}{|c|c|c|}
\hline & Control & Bacteria consortia \\
\hline Growth [dry wt. (g)] & $0.83 \pm 0.01$ & $8.7 \pm 0.5^{*}$ \\
\hline $\mathrm{pH}$ & $11.08 \pm 0.01$ & $10.48 \pm 0.03$ \\
\hline EC (MS/cm) & $2.89 \pm 0.04$ & $0.74 \pm 0.01$ \\
\hline Organic carbon (\%) & $0.43 \pm 0.01$ & $1.13 \pm 0.07^{*}$ \\
\hline Organic matter (\%) & $0.75 \pm 0.3$ & $2.03 \pm 0.75^{*}$ \\
\hline Total Nitrogen (mg/kg) & $5.68 \pm 0.2$ & $29.3 \pm 0.7^{*}$ \\
\hline
\end{tabular}

Liao et al. [29] isolated seven fungi and 32 alkaline microbes from the bauxite residue disposal area (BRDA) located in China. However, only one species demonstrated the potential to produce a great amount of acid. The strain EEEL01 was characterized as a new species of fungi and was identified as Penicillium oxalicum. The study concluded that the optimum conditions for EEEL01 growth and acid production used glucose and peptone as a carbon and nitrogen source, respectively, $\mathrm{pH} 9$ and $0.8 \% \mathrm{NaCl}$ concentration. In general, the diversity of filamentous fungi that can grow at high ambient $\mathrm{pH}$ values (i.e., 8-11) remains largely understudied [30]. Therefore, many efforts should be made to know the fungal species that can tolerate high alkalinity and can be used in future applications. Forty-eight other microorganisms were also isolated by Hao et al. (2019) from BRDA in the Guangxi Branch, China. Eight strains demonstrated the ability to reduce $\mathrm{pH}$ under an alkaline condition, however only strain EEEL02 was selected to be characterized due to the superior growth pattern and $\mathrm{pH}$ reduction performance. This strain was identified as Bacillus thuringiensis with optimum acid production at $\mathrm{pH} 10,2 \% \mathrm{NaCl}$ concentration, $25{ }^{\circ} \mathrm{C}$, glucose as a carbon source and beef extract as a source of nitrogen. Studies on the microbial community in bauxite residue can also be found in the literature. [10] analyzed the microbial diversity from bauxite residue and compared it to the other extreme environments. They observed that diversity in BR was similar at the phylum level with environments of alkaline lagoons, nuclear waste and oil residues, but was different in other taxonomic levels. The first study that characterized fungal communities in BR is described by [10]. The analysis concluded that the community was dominated at the phylum level by Ascomycota and Basidiomycota, which were also found in the hypersaline environment. They analyzed 3437 bacterial operational taxonomic units (OTUs) and 808 fungal OTUs. They then compared them to cultured representative sequences as recorded in the NCBI GenBank RefSeq 16S rRNA database. The authors concluded that despite BR being less diverse than natural analogues, it has harbored substantial novel bacterial taxa, with $90 \%$ of OTUs non-matchable to cultured representative sequences. [31] analysed the bacterial community from a sample of a drainage water reservoir collected at the highly alkaline ( $\mathrm{pH} 13)$ brown mud disposal site in the Banská Bystrica region, Slovakia. They identified 85 genera of 10 bacterial phyla. The most abundant phyla were Proteobacteria, Firmicutes and Bacteroidetes with an abundance of $80.4 \%, 13 \%$ and $5.6 \%$, respectively. The genus with higher abundance was Sulfurospirillum spp. representing $45.19 \%$ of the whole bacterial population, followed by Pseudomonas spp. (13.76\%) and Exiguobacterium spp. (13.02\%). All these recent studies have attempted to understand the microbial groups that are able to survive in these alkaline residues and the adaptation of the cells. The isolation of these representatives can facilitate their application in biotechnological processes to make the development of waste treatment more efficient.

\section{Phylogeny of Alkaliphilic Bacteria}

Alkaliphilic microorganisms are widespread in nature and phylogeny is diverse as well. The first alkaliphilic microorganism was isolated by [32] and it was an aerobic, endospore-forming, obligate alkaliphilic bacterium Bacillus alcalophilus. According to [28,33], studies about alkaliphilic bacteria emerged in this research area at the beginning of the 1960s. In addition, the first paper concerning an alkaline enzyme of alkaliphilic microorganisms was published in 1971 [34]. After these years, the diversity of alkaliphilic bacteria was studied by different researchers [35,36,37]. Thus, these efforts contributed to a number of known alkaliphiles and their diversity increased significantly. Thus, it was possible to understand the groups that developed the ability to survive in environments with such high $\mathrm{pH}$ values. After years of research, it can be observed that alkaliphiles have remarkably diverse ecological niches, e.g., ranging from alkaline soda lakes [36,38], the hind-gut of insects Thongaram et al. [39], to soils subjected to ammonification from industrial processes that generate high $\mathrm{pH}$ Jones et al. [36]. Besides that, there is the alkaline hydrothermal vent, another interesting environment which has been proposed to recapitulate conditions that existed during the formation of early life forms Herschy et al. [40]. Phylogenetic diversity also accompanies these diverse ecological niches. Thus, alkaliphilic microorganisms can be found in the three domains: Bacteria, Archaea and Eukarya [28] figure 2. Besides that, a variety of physiological groups can be found tolerating alkaline environments, for example natural alkaline environments which support the growth of microorganisms hold both aerobic and anaerobic extremophiles [28]. Among the aerobic alkaliphilics, there are: Bacillus, Micrococcus, Pseudomonas, and Streptomyces and eukaryotes, such as yeasts and filamentous fungi that have been isolated from a variety of environments Duckworth et al. [37], Groth et al. [41]. Regarding anaerobic alkaliphilics, there are many species that have been described: Clostridium sp, Anaerobranca horikoshii, Amphibacillus xylanus, Thermococcus alcaliphilus, Thermococcus sp Figure 3. 


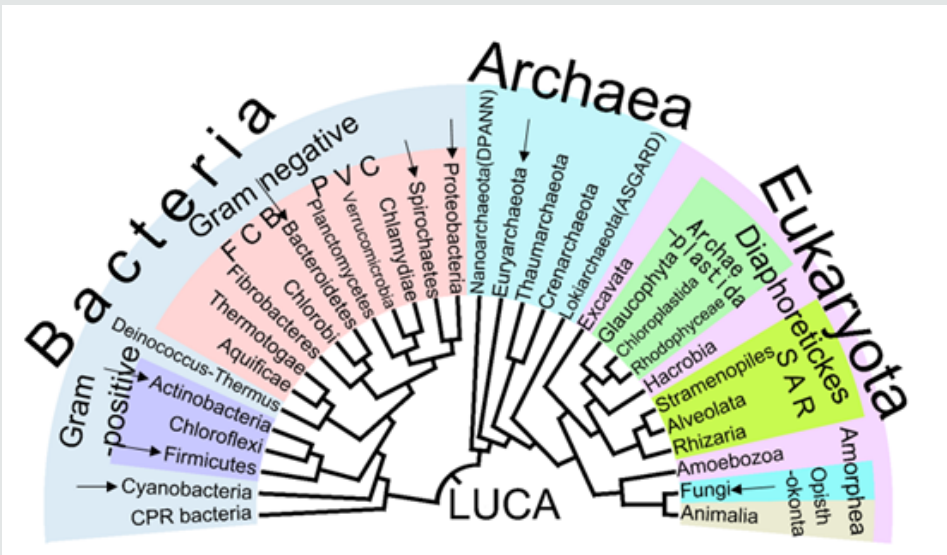

Figure 2: The universal phylogenetic tree of life is based on small subunit rRNA gene sequences and the distribution of alkaliphilic microorganisms within the tree. Groups marked with black arrows contain at least one halophilic representative. [50].

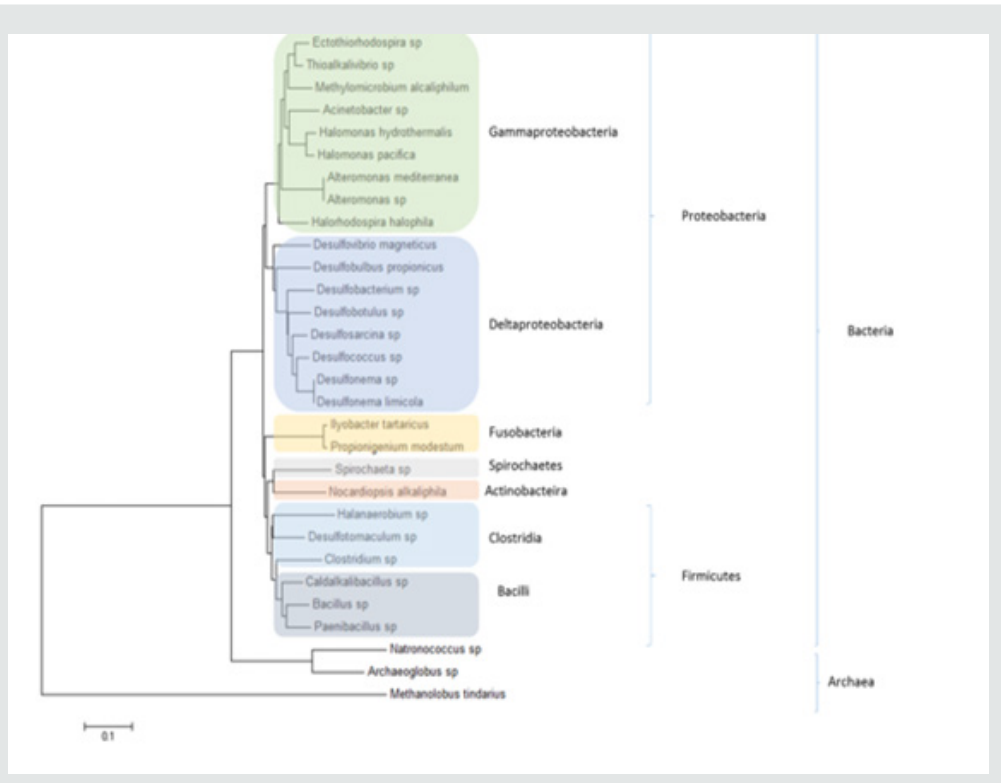

Figure 3: Phylogenetic tree based on nearly 16S complete ribossomal RNA sequences of some groups of Alkaliphylic microorganisms.

Many of these alkaline environments, such as alkaline lakes, are also characterized by high salt concentrations, so that the microorganisms that live in this place should have alkaliphilic, as well as halophilic properties. Thus, many alkaliphilic bacteria are members of the Halobacteriaceae, the family of halophiles that are obligatory alkaliphilic as well Oren, 2002. In this kind of natural alkaliphilic environment, the primary productivity is due to the presence of dense populations of alkaliphilic cyanobacteria, such as Spirulina spp. and alkaliphilic anoxygenic phototrophic Bacteria of the genus Ecrothiorhodospiru [42]. Soda lakes also contain dense populations of aerobic organotrophic and alkaliphilic Bacteria supported by the primary productivity. The following are some examples: Marinospirillum spp. [43], Alkalimonas spp. [38], and Aquisalimonas spp. Márquez et al. [44]. Again, particularly abundant were members of the high $\mathrm{G}+\mathrm{C}$ Bacillus spectrum Carrasco et al. [45], Salsuginibacillus Carrasco et al. [44], Aquisalibacillus Márquez et al. [44], Sediminibacillus Carrasco et al. [46]. Amphibacillus haojiensis Zhao et al. 2004, and Halolactibacillus Cao et al. [47]. The halomonads (members of the Halomonadaceae similar to $\mathrm{H}$. magadiensis) are probably the most important group of bacterial heterotrophs in alkaline environments, although other proteobacteria related to pseudomonads and vibrios are also present Duckworth et al. [37]. Generally, heterotrophic Grampositive bacteria of both the high $\mathrm{G}+\mathrm{C}$ (Firmicutes) and low $\mathrm{G}+\mathrm{C}$ (Actinobacteria) lineages are also abundant Grant \& Sorokin, 2011. Some examples can be found in Figure 3. There are also important groups at Archaea that could tolerate high salt concentrations. Within the Euryarchaeota group, there is the Halobacteria group 
whose representatives have physiological adaptations to tolerate in the methane cycle, Methanosarcinacea and Methanobacteriaceae high concentrations of salt. There are also groups that are important Figure 4.

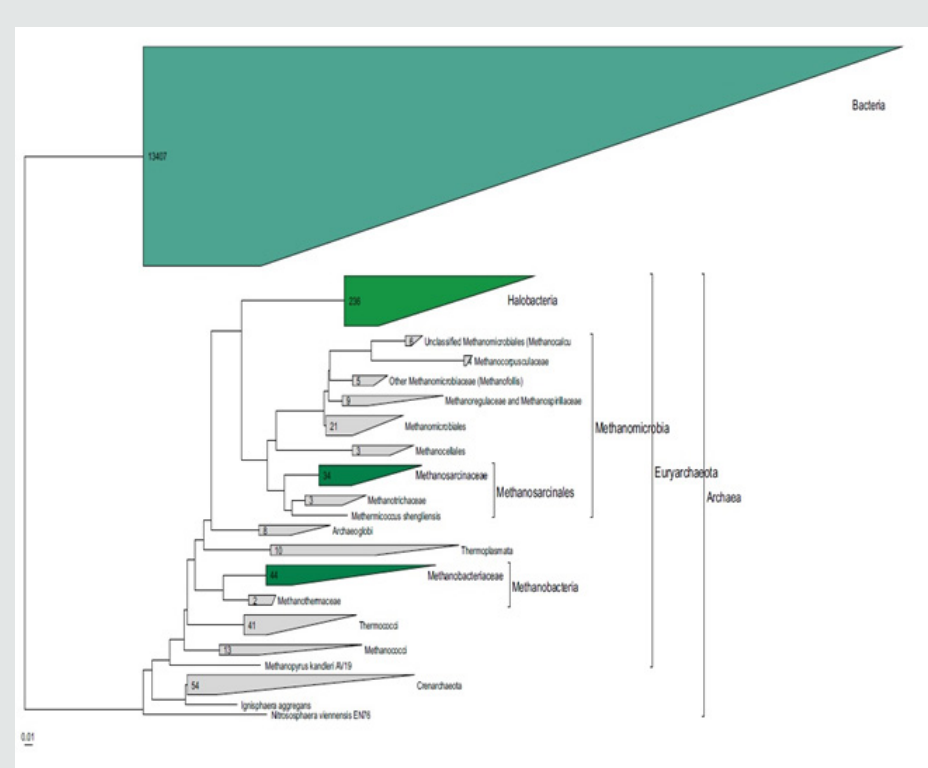

Figure 4: Phylogenetic tree of the Archaea Domain based on the complete ribosomal RNA sequence. The alkaliphilic groups are highlighted in green.

Table 5: Carbon substrate fermentation, exudation of organic acids, and survival at different alkalinity range of the representative isolates of red mud [23].

\begin{tabular}{|c|c|c|c|c|c|c|c|c|}
\hline \multirow{2}{*}{ Bacterial isolate } & \multirow{2}{*}{ Acid from carbon substrate ${ }^{\#}$} & \multirow{2}{*}{$\begin{array}{l}\text { Organic acid pro- } \\
\text { duction* }\end{array}$} & \multicolumn{6}{|c|}{ Alkalinity $^{\mathrm{b}}$ ( $\mathrm{pH}$ tolerance) } \\
\hline & & & 7 & 8 & 9 & 10.5 & 11.3 & 12 \\
\hline RM9P & Glucosamine, ribose & AA & +++ & +++ & +++ & +++ & +++ & - \\
\hline RM10E & Dextrose, trehalose, maltose, & AA & +++ & +++ & - & - & - & - \\
\hline RM10D & $\begin{array}{c}\text { Fructose, dextrose, mannose, salicin, glucosamine, } \\
\text { mannitol, ribose, rhamnose, cellobiose, melezi- } \\
\text { tose, d-arabinose }\end{array}$ & $\mathrm{AA}$ & +++ & +++ & - & - & - & - \\
\hline RM11R & Lactose, glucosamine, mannitol, ribose & - & - & +++ & +++ & +++ & - & - \\
\hline RM12W & Ribose, glucosamine, mannitol, lactose, & AA & +++ & +++ & +++ & +++ & - & - \\
\hline RM13Y & Glucosamine, ribose & - & - & +++ & ++ & - & - & - \\
\hline RM1 & Maltose, dextrose, ribose & - & +++ & +++ & ++ & ++ & - & - \\
\hline RM1A & $\begin{array}{l}\text { Lactose, xylose, maltose, fructose, dextrose, ga- } \\
\text { lactose, l-arabinose, mannose, sodium gluconate, } \\
\text { rhamnose, }\end{array}$ & $\mathrm{AA}$ & +++ & +++ & - & - & - & - \\
\hline RM6 & $\begin{array}{l}\text { Lactose, xylose, maltose, fructose, dextrose, galac- } \\
\text { tose, raffinose, trehalose, melibiose, l-arabinose, } \\
\text { mannose, inulin, salicin, inositol, mannitol, ribose, } \\
\text { rhamnose, melezitose, d-arabinose }\end{array}$ & $\mathrm{AA}, \mathrm{SA}$ & - & +++ & ++ & - & - & - \\
\hline RM8 & $\begin{array}{l}\text { maltose, fructose, dextrose, trehalose, glycerol, } \\
\text { salicin, mannitol, cellobiose, d-arabinose }\end{array}$ & AA & + & +++ & +++ & +++ & +++ & - \\
\hline
\end{tabular}

* - no acid production, AA acetic acid, SA succinic acid

b- no growth, + poor growth, ++ good growth, +++ luxurious growth 


\section{Use of Alkaliphilic microorganisms to treat Bauxite Residue}

Some studies are trying to take advantage of the metabolism of alkaline bacteria for biotechnological applications. One such application is the treatment of extremely alkaline effluents, such as RB. Hamdy and Williams [25] used a consortium of alkaliphilic bacteria and provided nutrients for the treatment of laboratoryscale bauxite waste under aerobic and anaerobic conditions. The results obtained were positive in both aerobic and anaerobic conditions within 24 hours. Although bacterial growth was more favorable under aerobic medium, it was under an anaerobic condition that the $\mathrm{pH}$ decreased in three units, improving the ability to reduce the alkalinity of the medium. In the same study, they tested the growth of plants in BR (bench scale) and after 34 days of treatment (addition of nutrients that favored the biomass growth, and consequently reduced the $\mathrm{pH}$ ) and untreated BR (as the control). The results indicated the growth of plants, which remained alive for more than 300 days where there was treatment, and in the untreated BR, plants died within 24 hours. Restoration of vegetation in the waste disposal areas is an alternative to mitigating the dispersion of dust. The revegetation of these areas minimizes soil erosion, wind action on particle disintegration, and consequently on dust formation, in addition to making the environment more favorable to the growth of the microbiota Gräfe et al. 2009. Liao et al. [29] investigated the effect of salinity, pH, source of carbon and nitrogen on alkaliphilic strain growth. The study showed that the optimal $\mathrm{pH}$ conditions for acid production by isolated alkaliphilic bacteria are between $\mathrm{pH} 8$ and 9 and they were able to reduce this $\mathrm{pH}$ to 3.4 in 9 days. Nevertheless, they also achieved great results in $\mathrm{pH} 10,11$ and 12 when after 9 days of incubation the pH decreased to 7.3, 7.3 and 8.4, respectively. Using glucose, maltose and sucrose as a carbon source in $\mathrm{pH} 9$ media, the strain produced a great amount of acids reducing the $\mathrm{pH}$ to 2.5 . Krishna et al. [23] used alkaliphilic microorganisms to treat BR in India. After six months of treatment with the microorganisms in the $\mathrm{BR}$, there was an improvement in the physical-chemical properties of the medium when compared to the control (without treatment). The $\mathrm{pH}$ of the medium decreased from 11 to 10.5 , there was a reduction in the values of the electrical conductivity, an increase in the organic carbon, available phosphorus and total nitrogen in the medium, besides a significant growth of grams where there was treatment with the consortium of bacteria Krishna et al. [23] Table 5 shows the improvements of the medium after biological treatment.

Ghorbani et al. [24] studied the possibility of using fungi in the biological leaching of the aluminum present in the red mud and the behavior of the $\mathrm{pH}$ in the presence of microorganisms. They verified that after the treatment with fungi, there was a decay in the $\mathrm{pH}$ of the medium, production of citric and oxalic acids and recovery of the metals, aluminum and titanium. Hao et al. 2019 isolated alkaliphilic strains and used them to neutralize BR under an optimum condition and in the study, the sugar metabolized by it was efficiently converted in acetic acid and propionic acid responsible for a pH decrease from 10.26 to 5.62 after 5 days. A recent study from You et al. [48] aimed to evaluate the effectiveness of the bioneutralization process in the bauxite residue, through microbial decomposition of organic matter and organic acid production under water-saturated conditions. The addition of $\mathrm{CaSO}_{4}$ and organic matter in the BR did significantly lower the $\mathrm{pH}$. This neutralizing effect induced by microbial decomposition of admixed organic matter was largely attributed to the generation of large amounts of organic acids. The production of organic acids in the OM-amended BR may be associated with the general function of diverse organotrophic bacteria as: Enterobacteriales, Pseudomonas, Bacillus, Halomonas, and Pasteurellaceae. These studies enforce the theory that, by providing a source of carbon to the microorganisms present in extreme environments, in order to promote cell growth, they are able to improve the physicochemical structures of the bauxite residue, favoring the adaptation of other microorganisms, plants and even animals. All these studies presented in this section shows that the treatment of BR with alkaliphilic microorganisms can be a reality and a part of a more efficient and cheaper treatment method.

\section{Conclusion}

The study of alkaliphiles has been the subject of many scientists. Knowledge of the major groups of organisms that can survive in high $\mathrm{pH}$ environments is broad. We need to know the alkaliphilic microorganisms present in the various biomes, as well as their nutritional needs. With the new sequencing techniques, the community presented in alkaline environments can be studied. However, efforts to isolate alkaliphilic strains are very important to stimulate bacterial growth under extreme conditions presented in BR, improving the use of these strains in the treatment of alkaline residues. A very important application in using these microorganisms is the treatment of BR. Recent studies show that it is possible to increase the $\mathrm{pH}$ through acid production by alkaliphilic bacteria and fungi. However, the experiments are still on a laboratory scale. An enormous amount of BR is produced each year and is stored in large reservoirs; therefore, it is important that future studies focus on developing this treatment on an industrial scale. In this context, the definition of nutritional conditions needed to promote the growth of alkaliphilic microorganisms capable of reducing this high alkalinity of the residues is a great challenge.

\section{References}

1. Habashi F (2005) A short history of hydrometallurgy. Hydrometallurgy 79(1): 15-22.

2. Gräfe M, Klauber C (2011) Bauxite Residue Issues: Iv. Old Obstacles And New Pathways For In Situ Residue Bioremediation. Hydrometallurgy 108(1-2): 46-59.

3. Power G, Gräfe M, Klauber C (2008) Bauxite Residue Issues: I. Current Management, Disposal and Storage Practices. Hydrometallurgy 108(12): $33-45$.

4. Tsakiridis Pe, Agatzini Leonardou S, Oustadakis P (2004) Red Mud Addition in The Raw Meal For The Production Of Portland Cement Clinker. J Hazard Mater 116(1-2): 103-110. 
5. Li H, Liu L, Luo L, Liu Y, Wei J, et al. (2018) Response of soil microbial communities to red mud-based stabilizer remediation of cadmiumcontaminated farmland. Environmental Science and Pollution Research 25(12): 11661-11669.

6. Segura FR, Nunes EA, Paniz FP, Paulelli ACC, Rodrigues GB (2016) Potential risks of the residue fromSamarco'smine damburst (Bento Rodrigues, Brazil). Environ Pollut 218: 813-825.

7. Carmo FF, kamino lHY, Junior RJ, Campos IC, Carmo FF (2017) Fundão tailings dam failures: the environment tragedy of the largest technological disaster of Brazilian mining in global context. Perspectives in Ecology and Conservation 15(3): 145-151.

8. Hatje V, Pedreira RMA, Rezende CE, Schettini CAF, Souza GC (2017) The environmental impacts of one of the largest tailing dam failures worldwide. Scientific Reports 7(1): 10706.

9. Winkler D Bidló A, Bolodár varga B, Erdő A, Horváth A (2018) Long-term ecological effects of the red mud disaster in Hungary: Regeneration of red mud flooded areas in a contaminated industrial region. Science of the Total Environment 644: 1292-1303.

10. Santini TC, Warren IA, Kendra KE (2015) Microbial diversity in engineered haloalkaline environments shaped by shared geochemical drivers observed in natural analogues. Appl Environ Microbiol 81(15): 5026-5036.

11. Sutar H, Mishra SC, Sahoo Sk, Prasad Chakraverty A, Maharan HS (2014) Progress of Red Mud Utilization: An Overview. American Chemical Science Journal 4(3): 255-279.

12. Bray AW, Stewart DI, Courtney R, Rout S, Humphreys PN, et al. (2018) Sustained bauxite residue rehabilitation with gypsum and organic matter 16 years after initial treatment. Environ Sci Technol 52(1): 152161.

13. Brunori C, Cremisini C, Massanisso P (2005) Reuse of a treated red mud bauxite waste: Studies on environmental compatibility. J Hazard Mater 117(1): 55-63.

14. Rai S, Wasewar KL, Agnihotri A (2017) Treatment of alumina refinery waste (red mud) through neutralization techniques: A review. Waste Manag Res 35(6): 565-580.

15. Paramguru Rk, Rath PC, Misra VN (2004) Trends in red mud utilization - A review. Mineral Processing and Extractive Metallurgy Review 26(1): $1-29$.

16. Stanford K (2016) Red mud-addressing the problem. Aluminium Insider Nov 15.

17. Tabereaux A (2010) Hungarian Red Mud Disaster: Addressing Environmental Liabilities of Alumina Residue Storage and Disposal. Light Metal Age 68(5): 22-24.

18. Tabereaux A (2019) ARTICLE: Addressing the Challenge of Bauxite Residue. Light metal age.

19. Itskov Y, Mann V, Rusal UC (2015) Red Mud: Problems and Solutions, 21st Metal Bulletin Bauxite and Alumina Conference, Miami, FL, February 24-26.

20. Rai S, Kailas L Wasewar, Jyoti Mukhopadhyay, Changkyoo Yoo, Hasan Uslu (2012) Neutralization and Utilization of Red Mud for its Better Waste Management. Arch Environ Sci 6: 13-33.

21. Nogueira EW, Hayash EA, Alves E, Lima CAA, Adorno MT, et al. (2017) Characterization of akaliphilic bacteria isolated from bauxite residue in the Southern region of Minas Gerais, Brazil. Braz arch biol technol volume (60).

22. Preiss L, Hicks DB, Suzuki S, Meier T, Krulwich TA (2015) Alkaliphilic Bacteria with Impact on Industrial Applications, Concepts of Early Life Forms, and Bioenergetics of ATP Synthesis. Front Bioeng Biotechnol 3(3): 75.
23. Krishna P, Babu AG, Reddy MS (2014) Bacterial diversity of extremely alkaline bauxite residue site of alumina industrial plant using culturable bacteria and residue 16S rRNA gene clones. Extremophiles 18(4): 665676.

24. Ghorbani Y, Oliazadeh M, Shahvedi A (2008) Aluminum solubilisation from red mud by some indigenous fungi in Iran. Journal of Applied Biosciences 7: 207-213.

25. Hamdy MK, Williams FS (2001) Bacterial amelioration of bauxite residue waste of industrial alumina plants. Journal of Industrial Microbiology and Biotechnology 27(4): 228-233.

26. Agnew MD, Koval SF, Jarrell KF (1995) Isolation and characterization of novel alkaliphiles from bauxite-processing waste and description of Bacillus vedderi sp. nov., a new obligate alkaliphile. Systematic and Applied Microbiology 18(2): 221-230.

27. Aono R, Horikoshi K (1983) Chemical composition of cell walls of alkalophilic strains of Bacillus. Journal of General microbiology 129: 1083-1087.

28. Horikoshi K (1999) Alkaliphiles: Some applications of their products for biotechnology. Microbiol Mol Biol Rev 63(4): 735-750.

29. Liao K, Bai Y, Huo Y, Jian Z, Hu W, et al. (2018) Integrating microbial biomass, composition and function to discern the level of anthropogenic activity in a river ecosystem. Environ Int 116: 147-155.

30. Grum Grzhimaylo AA, Georgieva ML, Bondarenko SA, Debets AJM, Bilanenko EN (2015) On the diversity of fungi from soda soils. Fungal Diversity 76: 27-74.

31. Kisková J, Stramová Z, Javorský P, Sedláková Kaduková J, Pristaš P (2019) Analysis of the bacterial community from high alkaline $\mathrm{pH}>$ 13) drainage water at a brown mud disposal site near Žiar and Hronom (Banská Bystrica region, Slovakia) using 454 pyrosequencing. Folia Microbiol 64(1): 83-90.

32. Vedder A (1934) Bacillus alcalophilus n. sp. Benevens enkele Ervaringen met sterk alcalische Voedingsbodems. Antonie van Leeuwenhoek 1(1): 141-147.

33. Horikoshi K (1996) Alkaliphiles-from an industrial point of view. FEMS Microbiol Lett 18(2-3): 259-270.

34. Horikoshi K (1971) Production of alkaline enzymes by alkalophilic microorganisms. Part 1. Alkaline protease produced by Bacillus No, 221. Agric. Biol. Chem 36(9): 1407-1414.

35. Tindall BJ, Ross HNM, Grant WD (1984) Natronobacterium gen. nov. and Natronococcus gen. nov., two genera of haloalkalophilic archaebacterium. Syst. Appl. Microbiol 5(1): 41-57.

36. Jones BE, Grant WD, Duckworth AW, Owenson GG (1998) Microbial diversity of soda lakes. Extremophiles 2(3): 191-200.

37. Duckworth AW, Grant W D, Jones BE, Vansteenbergen R (1996) Phylogenetic diversity of soda lake alkaliphiles. FEMS Microbiol. Ecol 19(3): 181-191.

38. Ma Y, Xue Y, Grant WD, Collins NC, Duckworth AW, et al. (2004) Alkalimonas amylolytica gen. nov. sp. nov. and Alkalimonas delamerensis gen. nov. sp. nov. novel alkaliphilic bacteria from soda lakes in China and East Africa. Extremophiles 8(3): 193-200.

39. Thongaram T, Kosono S, Ohkuma M, Hongoh, Y, Kitada M, et al. (2003) Gut of higher termites as a niche for alkaliphilesas shown by culturebased and culture-independent studies. Microb Environ 18: 152-159.

40. Herschy B, Whicher A, Camprubi E, Watson C, Dartnell L, et al. (2014) An Origin-of-Life Reactor to Simulate Alkaline Hydrothermal Vents. Journal of Molecular Evolution 79(5-6): 213-227.

41. Groth I, Schumann P, Rainey FA, Martin K, Schuetze B, et al. (1997) Bogoriella caseilytica gen. nov., sp. nov, a new alkaliphilic actinomycete 
from a soda lake in Africa. Int J Syst Bacteriol 47(3): 788-794.

42. Grant WD, Tindall BJ (1986) The alkaline saline environment. In: Microbes in Extreme Environments Academic Press. London pp. 25-54.

43. Zhang W, Xue Y, Ma Y, Grant W, Ventosa A, et al. (2002) Marinospirillum alkaliphilum sp. nov., a new alkaliphilic helical bacterium from Haoji soda lake in Inner Mongolia Autonomous Region of China. Extremophiles 6(1): 33-37.

44. Carrasco J, Márquez MC, Xue Y, Ma Y, Cowan DA, et al. (2007) Salsuginibacillus kocurii gen. nov., sp. nov., a moderately halophilic bacterium from sediment of a soda lake. Int J Syst Evol Microbiol 57 2381-2386.

45. Carrasco J, Márquez MC, XueY, MaY, Cowan DA, etal. (2006) Gracilibacillus orientalis sp. nov., a novel moderately halophilic bacterium isolated from a Salt Lake in Inner Mongolia, China. Int J Syst Evol Microbiol 56: 599604.

46. Carrasco J, Márquez MC, Xue Y, Ma Y, Cowan DA, et al. (2008) Aquisalibacillus elongatus gen. nov., sp nov., a moderately halophilic bacterium of the family Bacillaceae isolated from a saline lake. Int J Syst Evol Microbiol 58: 1922-1926.

47. Cao SJ, Qu JH, Yang JS, Sun Q Yuan HL (2008) Halolactibacillus alkaliphilus sp. nov., a moderately alkaliphilic and halophilic bacterium isolated from a soda lake in Inner Mongolia, China, and emended description of the genus Halolactibacillus. Int. J. Syst. Evol. Microbiol 58: 2169-2173.
48. Kwangsuk Y, Dong Wan C, Yiu FT, Daniel CW, Eilhann E, Kwon HS (2019) Synthesis of functionalised biochar using red mud, lignin, and carbon dioxide as raw materials. Chemical Engineering Journal 361: 1597-1604.

49. Bagshaw Tony 2017. The Aluminium Story Bauxite To Alumina: The Bayer Process An Introductory Text. Perth.

50. Oren A (2008) Microbial life at high salt concentrations: Phylogenetic and metabolic diversity. Saline systems 4: 1-13.

51. WAO - World Aluminium Organization (2019).

52. Wu H, Liao J, Zhu F, Graeme M, Ronan C, et al. (2019) Isolation of an acid producing Bacillus sp. EEEL02: Potential for bauxite residue neutralization [J]. Journal of Central South University 26(2): 343-352.

53. Tabereaux A (2012) The discovery, commercialization, and development of the aluminium industry in France 70: 28-33.

54. Oren A (2000) Life at high salt concentrations. In the Prokaryotes: An Evolving Electronic Resource for the Microbiological Community.

55. Marquez MC, Carrasco IJ, Xue Y, Ma Y, Cowan DA, et al. (2007) Aquisalimonas asiatica gen. nov., sp. nov., a moderately halophilic bacterium isolated from an alkaline, saline lake in Inner Mongolia, China." Int. J. Syst. Evol. Microbiol 57: 1137-1142.

56. Grant WD, Mwatha WE, Jones BE (1990) ALKALIPHILES: Ecology, diversity, and applications. FEMS Microbiol. Lett 6(2-3): 255-269.

\section{(c) (1) \\ This work is licensed under Creative Commons Attribution 4.0 License}

To Submit Your Article Click Here: Submit Article

DOI: $10.32474 / J O M M E .2019 .01 .000107$

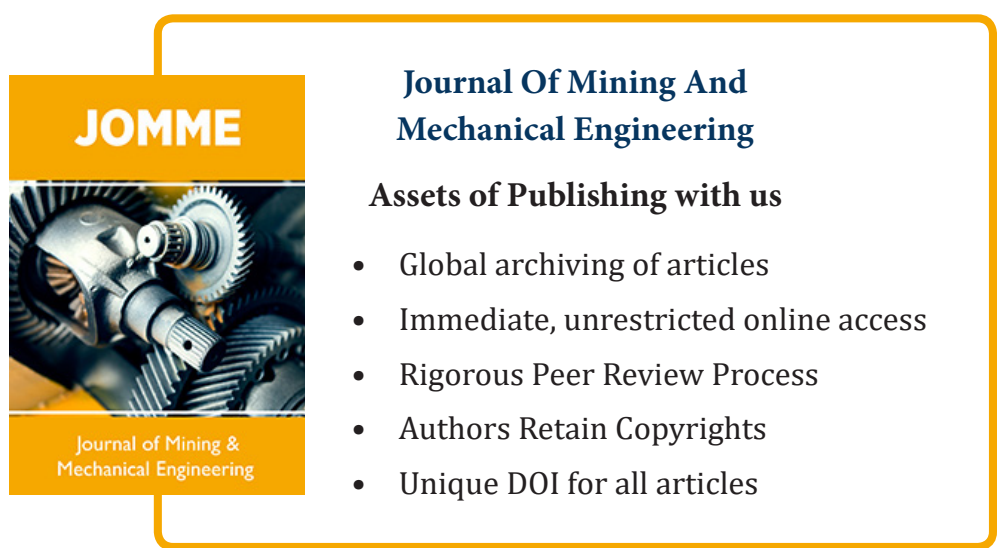

